\title{
Polycyclic Aromatic Hydrocarbon-degrading Bacteria from Aviation Fuel Spill Site at Ibeno, Nigeria
}

\author{
R. C. John · J. P. Essien · S. B. Akpan • \\ G. C. Okpokwasili
}

Received: 20 October 2011/Accepted: 10 March 2012/Published online: 29 March 2012

(C) The Author(s) 2012. This article is published with open access at Springerlink.com

\begin{abstract}
Polycyclic aromatic hydrocarbon (PAH)degrading bacteria were isolated from aviation fuel contaminated soil at Inua Eyet Ikot in Ibeno, Nigeria. PAH-degrading bacteria in the contaminated soil were isolated by enrichment culture technique. Isolates with high PAH degrading potential characterized by their extensive growth on PAH-supplemented minimal salt medium were screened for their naphthalene, phenanthrene and chrysene degradability. The screening medium which contained selected PAHs as the sole source of carbon and energy showed that Micrococcus varians AFS-2, Pseudomonas putida AFS-3 and Alcaligenes faecalis AFS-5 exhibited a concentration-dependent growth in all the PAH-compounds tested. There were visible changes in the color of growth medium suggesting the production of different metabolites. Their acclimation to different PAH substrates was also evident as A. faecalis AFS-5 isolated from chrysene grew well on other less complex aromatic compounds. The isolate exhibited best growth $\left(0.44 \mathrm{OD}_{600}\right)$ when exposed to $10 \mathrm{ppm}$ of chrysene for 5 days and could utilize up to $90 \mathrm{ppm}$ of chrysene. This isolate and others with strong PAHdegrading potentials are recommended for bioremediation of PAHs in aviation fuel-contaminated sites in the tropics.
\end{abstract}

Keywords Biodegradation - Polyaromatic hydrocarbons · Aviation Fuel-polluted soil

R. C. John · G. C. Okpokwasili

Department of Microbiology, University of Port Hacourt,

Port Hacourt, Rivers State, Nigeria

R. C. John $(\bowtie)$ · J. P. Essien · S. B. Akpan

Department of Microbiology, University of Uyo, Uyo,

Akwa Ibom State, Nigeria

e-mail: richritom7@yahoo.com
Polycyclic aromatic hydrocarbons (PAHs) are chemical compounds that consist of fused aromatic rings and do not contain heteroatoms or carry substituents (Fetzer 2000). They are produced during fossil fuel combustion, waste incineration, or as by-products of industrial processes such as coal gasification, production of aluminum/iron/steel and petroleum refining, component of wood preservatives, smoke houses and wood stoves (Shuttleworth and Cerniglia 1995; Gemma et al. 2006). While low-molecular-weight (LMW) PAHs (composed of two or three fused benzene rings) are readily degraded by bacteria, high-molecularweight (HMW) PAHs consisting of four rings or more are recalcitrant to biodegradation and persist in the environment (Wilson and Jones 1993; Cerniglia 1992).Therefore, the chemical properties and hence the environmental fate of PAH molecules are dependent in part upon molecular size. Generally, an increase in the size and angularity of a PAH molecule results in a concomitant increase in hydrophobicity and electrochemical stability. PAH molecule stability and hydrophobicity are two primary factors which contribute to the persistence of PAHs in the environment. Consequently, they have been detected in numerous aquatic and terrestrial ecosystems at concentrations high enough to warrant concern about bioaccumulation.

Despite the fact that some physical processes such as volatilization, leaching, chemical and photo oxidation which are effective in reducing the environmental level of PAHs (Heitkamp et al. 1988), biodegradation using microorganisms is usually the preferred and major route of PAH removal from contaminated environments because of its cost effectiveness and complete clean-up (Pothuluri and Cerniglia 1994). Besides, the physical processes are often limited to aquatic environments only. Expectedly, PAHs-degrading microorganisms should possess all the necessary enzymes needed to degrade PAHs. However, it is established that 
biodegradation of PAHs as well as other chemicals occurs as a result of previous exposure to these substances in the environment (Lewis et al. 1984). Adaptation occurs slowly and usually depends on the recalcitrance or biodegradability of the particular substances involved (Spain et al. 1980). This is especially so considering the low aqueous solubility of PAHs which ensures its low bioavailability for microbial utilization (Jonsen et al. 2005). Several species of microorganisms have been successfully utilized in major hazardous waste clean-up processes (Levinson et al. 1994). Abd-El-Haleem et al. (2009) have reported that 2-3 ring PAHs (naphthalene, anthracene and phenanthrene) can be degraded using Pseudomonas geniculata and Achromobacter xylosoxidans. On the other hand, microbial degradation of high molecular weight (HMW) PAHs including chrysene classified among the priority pollutants by the U.S. Environmental Protection Agency (Smith et al. 1989) is vital to the clean-up of polluted soils and water systems (Alexander 1999; Atlas 1981). Bacterial isolates capable of chrysene metabolism have been described. These include Rhodococcus sp. strain UW1 (Walter et al. 1991), Sphingomonas yanoikuyae which oxidized chrysene (Boyd et al. 1999) while Pseudomonas fluorescens utilised chrysene and benz[a]anthracene as sole carbon sources (Caldini et al. 1995).

There is limited information on microbial degradation of polycyclic aromatic hydrocarbons including chrysene in crude oil-impacted Niger Delta ecosystem. In this work, we report the isolation and characterization of naphthalene, phenanthrene and chrysene-degrading bacteria from aviation fuel contaminated soil in Ibeno, Nigeria.

\section{Materials and Methods}

With the aid of sterile spatula, soil samples were aseptically collected from different location in Aviation fuel contaminated site in Inua Eyet Ikot, Ibeno, Nigeria. All the samples were placed into sterile polythene bags, stored at $4^{\circ} \mathrm{C}$ in ice-packed coolers and then transported to the laboratory for analysis.

PAH degraders were isolated from soil samples using an enrichment medium containing either naphthalene, phenanthrene or chrysene as sole carbon and energy source (Kastner et al. 1994) The medium contained (per liter): $2.13 \mathrm{~g} \mathrm{Na} \mathrm{HPO}_{4}, 1.3 \mathrm{~g} \quad \mathrm{KH}_{2} \mathrm{PO} 4,0.5 \mathrm{~g} \mathrm{NH} 4 \mathrm{Cl}, 0.2 \mathrm{~g}$ $\mathrm{MgSO}_{4} \cdot 7 \mathrm{H}_{2} \mathrm{O}$ and trace elements solution (1 mL per liter) (Bauchop and Flsiden 1960). This was sterilized by autoclaving at $121^{\circ} \mathrm{C}$ for $15 \mathrm{~min}$. Thereafter, $0.2 \mathrm{~mL}$ acetone solution containing $0.1 \% \mathrm{w} / \mathrm{v}$ of the selected PAHs (naphthalene, phenanthrene or chrysene) was asceptically pipetted and uniformly spread on the agar surface of a pre-dried plate (West et al. 1984). The acetone was allowed to evaporate under sterile condition before inoculation with $0.1 \mathrm{~mL}$ of diluted soil samples. The inoculated plates were covered with foil and black polyethylene bag, and then incubated in the dark at room temperature for 14 days. Control plates free of test PAHs were also prepared and colonies on the control plates were counted and taken as oligotrophs able to grow on the test medium. Colonies that formed crystal clear zones on the PAH-coated plates were replicated onto fresh $\mathrm{PAH}$-coated agar plates and incubated for 14 days. Isolates that grew on these plates were selected as naphthalene, phenanthrene or chrysene degraders.

The isolates were purified repeatedly by sub-culturing and characterized according to procedures described by Cowan (2003) and Holt et al. (1994). The activity of catalase was determined by the appearance of air bubbles after addition of a drop of $30 \%$ hydrogen peroxide solution to an overnight grown single bacterial colony. To determine the ability of isolates to hydrolyze starch, $50 \mu \mathrm{L}$ of liquid cultures of each isolate were dropped on starch-based solid medium containing per liter, $3 \mathrm{~g}$ meat extract, $10 \mathrm{~g}$ starch and $15 \mathrm{~g}$ agar. The casein hydrolysis was determined by observing zones of clearing after one day of incubation. For this purpose, $50 \mu \mathrm{L}$ liquid culture of each isolate was dropped on casein-based solid medium containing (per liter) $10 \mathrm{~g}$ casein and $15 \mathrm{~g}$ agar After one day incubation, the inhibition zones were determined. Carbohydrate fermentation was determined by the production of gas during incubation. The test was performed for fructose, sucrose, glucose, xylose and lactose. Production of tryptophan deaminase was also detected by the color change of the medium after adding $10 \%$ ferric chloride. Glyceride hydrolysis and nitrate reduction tests were also conducted. In addition, the isolates were subjected to Gram's staining procedure (Harrigan and McCance 1976).

Growth of the different organisms was tested by growing each isolate in a large test tube containing $25 \mathrm{~mL}$ of the screening medium supplemented with $15 \mathrm{mg}$ of naphthalene, phenanthrene or chrysene which were dissolved in acetone and added to each tube after autoclaving. Thereafter, the test tubes were incubated at room temperature $\left(28 \pm 2^{\circ} \mathrm{C}\right.$ ) for five days. The ability of each isolate to utilize naphthalene, phenanthrene and chrysene was indicated by increase in turbidity of the medium measured at $600 \mathrm{~nm}$ using a UV spectrophotometer.

To determine the effect of PAH concentrations on the growth of the isolates, precisely $75 \mathrm{~mL}$ of enrichment medium was dispensed into thirty-six $250 \mathrm{~mL}$ flasks and sterilized by autoclaving. The flasks were then divided into six sets of six flasks. Thereafter, 50, 100, 150, 200, 250 and 300 ppm levels of naphthalene, phenanthrene and chrysene which were seperately dissolved in acetone (as before) were exposed to each isolate. Inoculated flasks were then incubated as previously described at $28^{\circ} \mathrm{C}$ for 5 days. Five 
millilitre sample was aseptically collected from each flask and assayed for the level of microbial growth. Cultures without increase in turbidity over initial optical density (OD) and uninoculated control were scored as no growth (-) while cultures with increased turbidity significantly greater than the control were scored as growth $(+)$, their OD readings were also measured with a UV spectrophotometer.

\section{Results and Discussion}

Our findings have shown that aviation fuel contaminated soil is mostly harboured by bacteria with PAH-degrading capabilities (Fig. 1). The PAH-degrading strains isolated from the soil are listed in Table 1. A total of $24 \mathrm{PAH}$-degrading bacterial isolates were obtained out of which 18 isolates demonstrated the ability to degrade naphthalene. Ten (10) isolates grew on phenanthrene while 14 isolates grew on chrysene (Table 2). Among the naphthalene-degrading isolates, AFS-2 exhibited very high degradability with $\mathrm{OD}_{600} \mathrm{~nm}$ of 0.296. Three isolates, AFS-2, AFS-3 and AFS5 , with high naphthalene-, phenanthrene- and chrysenedegrading capabilities were obtained and characterized. The isolates were respectively identified as Micrococcus varians AFS-2, Pseudomonas putida AFS-3 and A. faecalis AFS-5 (Table 3). Recently, members of the A. xylosoxidans capable of degrading PAHs have been isolated from wetland sediment (Wan et al. 2006). A. xylosoxidans, first described by Yabuuchi et al. (1974), was previously listed under the name Alcaligenes denitrificans subspecies xylosoxidans, an oligotrophic bacterium. In Nigeria the most common PAHdegrading bacterial isolates are Pseudomonas, Arthrobacter, Acinetobacter, Flavobacterium, Alcaligenes, Micrococcus and Corynebacterium (Okerentugba and Ezeronye 2003; Nwachukwu et al. 2000; Ilori and Amund 2000).

The ability of $M$. varians AFS-2, P. putida AFS-3 and $A$. feacalis AFS-5 to degrade naphthalene, phenanthrene and chrysene respectively at different levels of exposure are presented in Fig. 2. For isolate AFS-5, the least growth of $0.01\left(\mathrm{OD}_{600}\right)$ was observed at chrysene of $90 \mathrm{ppm}$ while the best growth of 0.44 was recorded when exposed to $10 \mathrm{ppm}$ of chrysene (Fig. 1c) for 5 days. Similarly, the least growth of $P$. putida AFS-3 was 0.015 when treated with $100 \mathrm{ppm}$ of phananthrene, while the highest was 0.098 at $10 \mathrm{ppm}$ of phenanthrene (Fig. 1b). The highest growth of $0.29\left(\mathrm{OD}_{600}\right)$ was recorded by $M$. varians AFS-2 treated with $10 \mathrm{ppm}$ of naphthalene (Fig. 1a). However, the growths of all the test isolates were PAH-dependent and provide strong evidence for selective $\mathrm{PAH}$ degradation by bacteria. The degradation and utilization of these compounds resulted in increase in optical density (cell mass) of the organisms. However, M. varians AFS-2 did not grow well under chrysene concentration range of
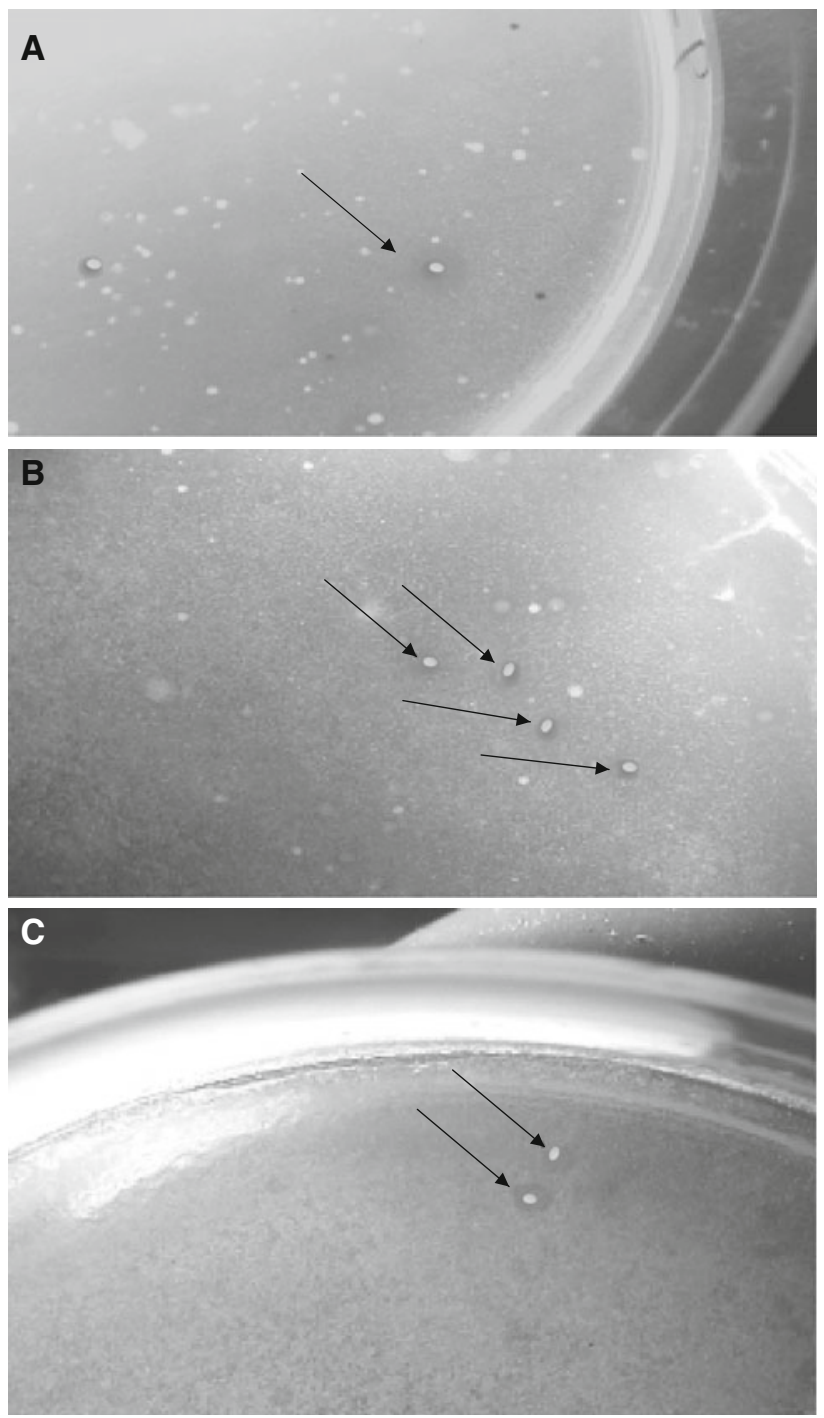

Fig. 1 Photograph of the PAH-degrading colonies surrounded by clear zone (arrow) of the white coating of PAH a naphthalene b phenanthrene c chrysene

$40-100 \mathrm{ppm}$. This inability to utilize the hydrocarbons may be attributed to membrane toxicity and non-possession of the necessary enzymes. Moreso, the lipophilic hydrocarbons accumulated in the membrane lipid bilayer and may affects the structural and functional properties of the membrane. It may also lead to loss of membrane integrity, increase in permeability to protons and consequently, dissipation of the proton motive force, and impairment of intracellular $\mathrm{pH}$ homeostasis (Sikkema et al. 1995).

Measuring the success of bioremediation of oil contaminated site is based on several parameters, among them the degradation of polycyclic aromatic hydrocarbons. The three bacterial isolates encountered in the contaminated soil were able to utilize chrysene, phenanthrene and naphthalene. Their ability to utilize both low and high molecular weight PAHs is an indication of the possession 
Table 1 PAH-degradability of bacterial Isolates from aviation fuel contaminated soil

\begin{tabular}{llll}
\hline Isolates code & PAH-degradability & & \\
& Naphthalene & Phenanthrene & Chrysene \\
\hline AFS-1 & ++ & ++ & ++ \\
AFS-2 & +++ & ++ & ++ \\
AFS-3 & ++ & +++ & ++ \\
AFS-4 & ++ & ++ & ++ \\
AFS-5 & ++ & ++ & +++ \\
AFS-6 & ++ & + & ++ \\
AFS-7 & ++ & ++ & ++ \\
AFS-8 & ++ & ++ & ++ \\
AFS-9 & ++ & ++ & ++ \\
AFS-10 & ++ & ++ & ++ \\
AFS-11 & ++ & ++ & \\
AFS-12 & + & ++ & \\
AFS-13 & ++ & + & \\
AFS-14 & ++ & ++ & \\
AFS-15 & ++ & & \\
AFS-16 & + & & \\
AFS-17 & + & & \\
AFS-18 & ++ & & \\
\hline
\end{tabular}

+++ , heavy growth;,++ moderate growth; + , weak growth
Table 3 Morphological and biochemical properties of the PAHdegrading bacterial isolates

\begin{tabular}{|c|c|c|c|}
\hline Parameter & A. faecalis & M. varians & P. putida \\
\hline Gram reaction & - & + & - \\
\hline Cellular morphology & Rods & Cocci & Short rods \\
\hline Catalase & + & + & + \\
\hline Oxidase & + & + & + \\
\hline Indole & - & - & - \\
\hline Motility & + & - & + \\
\hline Methyl red & - & - & - \\
\hline Voges-Proskauer & - & - & - \\
\hline Citrate & + & + & - \\
\hline Urease & - & - & - \\
\hline Starch hydrolysis & - & - & - \\
\hline Gelatin hydrolysis & - & + & - \\
\hline $\mathrm{NO}_{3}$ reduction & + & + & + \\
\hline Coagulase test & - & - & - \\
\hline Spore test & - & - & - \\
\hline Mannitol & - & - & - \\
\hline Glucose & + & + & + \\
\hline Xylose & - & + & + \\
\hline Lactose & - & - & - \\
\hline Sucrose & + & + & - \\
\hline Arabinose & - & - & - \\
\hline Maltose & - & + & - \\
\hline Galactose & + & - & - \\
\hline
\end{tabular}

Table 2 Growth performance (optical density) of the PAH- degraders on the different PAHs

\begin{tabular}{llll}
\hline Isolate code & \multicolumn{2}{l}{ Optical density $($ OD 600 nm) } \\
\cline { 2 - 4 } & Naphthalene & Phenanthrene & Chrysene \\
\hline AFS-1 & 0.133 & 0.080 & 0.432 \\
AFS-2 & $0.296^{\mathrm{a}}$ & 0.055 & 0.321 \\
AFS-3 & 0.114 & $0.098^{\mathrm{a}}$ & 0.155 \\
AFS-4 & 0.068 & 0.036 & 0.221 \\
AFS-5 & 0.082 & 0.052 & $0.445^{\mathrm{a}}$ \\
AFS-6 & 0.134 & 0.022 & 0.162 \\
AFS-7 & 0.084 & 0.058 & 0.199 \\
AFS-8 & 0.068 & 0.039 & 0.212 \\
AFS-9 & 0.042 & 0.043 & 0.208 \\
AFS-10 & 0.089 & 0.041 & 0.186 \\
AFS-11 & 0.098 & 0.048 & \\
AFS-12 & 0.02 & 0.065 & \\
AFS-13 & 0.026 & 0.026 & \\
AFS-14 & 0.110 & 0.064 & \\
AFS-15 & 0.042 & & \\
AFS-16 & 0.024 & & \\
AFS-17 & 0.028 & & \\
AFS-18 & 0.033 & & \\
\hline
\end{tabular}

\footnotetext{
${ }^{a}$ Isolates with strong degradability
}

of ring fission enzymes (Ilori and Amund 2000). Furthermore, it seems likely that the degradation of individual PAH compounds by the isolates proceeds via independent pathways (Bressler and Fedorak 2000; Van-Hamme et al. 2003). Alcaligenes faecalis AFS-5 resisted $90 \mathrm{ppm}$ of naphthalene respectively. However, the chrysene utilizing bacterium A. faecalisn AFS-5 was able to utilize other two tested PAH compounds. It is apparent from the results that strains isolated on chrysene (AFS-5) and phenanthrene (AFS-3) was able to grow better on the three tested PAHs than the strain isolated on naphthalene. These results agree with the observation of Alexander (1999) that the acclimation of microbial community to one substrate, may lead to the simultaneous acclimation to some but not all structurally related molecules. Also, individual microbial species have the ability to act on several structurally similar substrates and therefore more easily act on their analogues after the first addition (Bauer and Capone 1985; Mitchell and Cain 1996).

It is therefore not surprising that A. faecalis AFS-5 grew well on these other organic aromatic compounds, considering that they are all commonly composed of benzene chrysene. M. varians AFS-2 persisted sparingly in $100 \mathrm{ppm}$ 

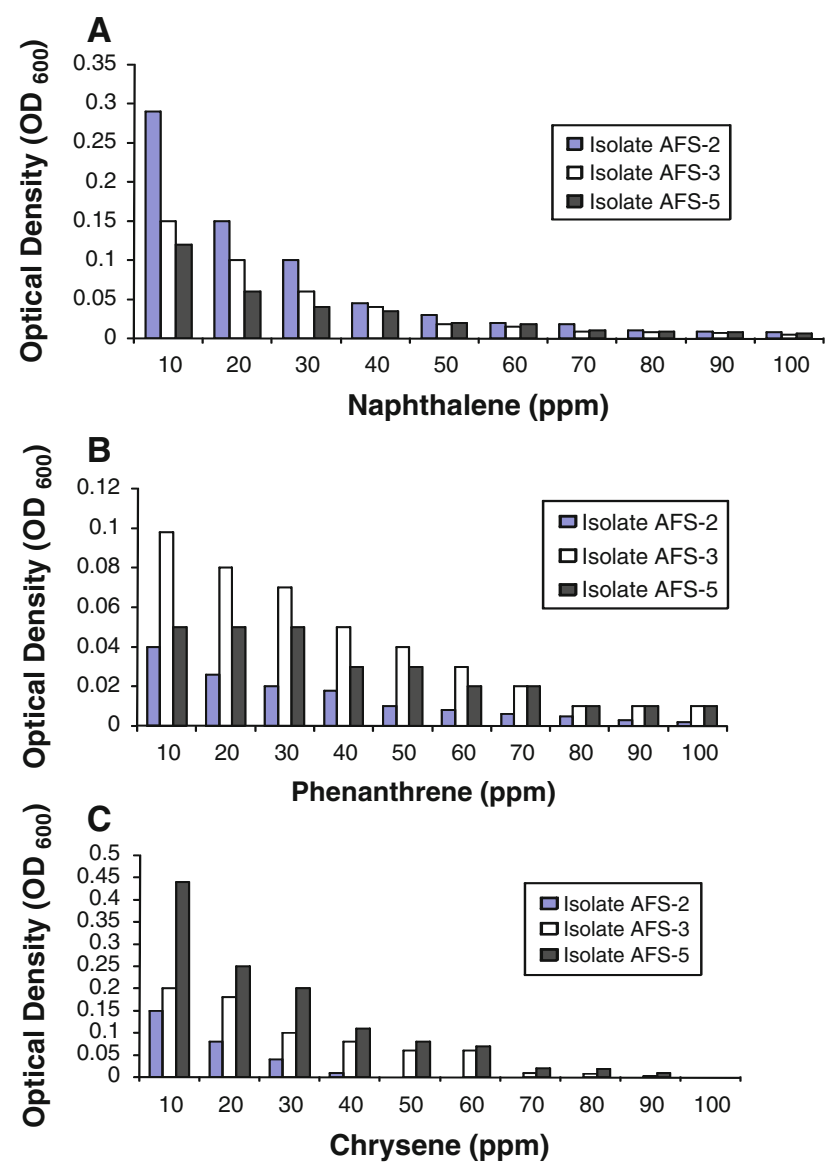

Fig. 2 Growth (optical density) of the selected PAH-degrading bacteria on different concentrations of naphthalene, phenanthrene and chrysene. AFS- $2=$ Naphthalene, AFS-3 = Phenanthrene, AFS$5=$ Chrysene

rings as phenanthrene (Okpokwasili et al. 1986). Investigation into the regulatory interactions within PAHdegrading consortia and the mechanisms by which HMW PAH biodegradation occur are underway and will prove helpful for predicting the environmental fate of these compounds which is vital to development of practical PAH bioremediation strategies in the future. The degradative capabilities of the evaluated organisms especially A. faecalis AFS-5 can be explored in bioremediation strategies for aviation fuel-impacted soil in Nigeria.

Open Access This article is distributed under the terms of the Creative Commons Attribution License which permits any use, distribution, and reproduction in any medium, provided the original author(s) and the source are credited.

\section{References}

Alexander M (1999) Biodegradation and bioremediation. Academic Press, San Diego

Atlas RM (1981) Microbial degradation of petroleum hydrocarbons: an environmental perspective. Microbiol Rev 45:180-209
Bauchop T, Flsiden SR (1960) The growth of microorganisms in relation to their energy. J Gen Microbiol 23:457-469

Bauer J, Capone D (1985) Degradation and mineralization of the polycyclic aromatic hydrocarbons anthracene and naphthalene in inter tidal marine sediments. Appl Environ Microbiol 50: $81-90$

Boyd DR, Sharma ND, Hempenstall F, Kennedy MA, Malone JF, Allen CCR, Rensnick SM, Gibson DT (1999) bis-cis-Dihydrodiols: a new class of metabolites from biphenyl dioxygenasecatalyzed sequential asymmetric cis-dihydroxylation of polycyclic arenas and heteroarenes. J Org Chem 64:4005-4011

Bressler D, Fedorak P (2000) Bacterial metabolism of fluorene, dibenzofuran, dibenzothiophene, and carbazole. Can J Microbiol 46:397-409

Caldini G, Cenci G, Manenti R, Morozzi G (1995) The ability of an environmental isolate of Pseudomonas fluorescens to utilize chrysene and other four-ring polynuclear aromatic hydrocarbons. Appl Microbiol Biotechnol 44:225-229

Cerniglia CE (1992) Biodegradation of polycyclic aromatic hydrocarbons. Biodegradation 3:351-368

Cowan ST (2003) Cowan and steels' manual for the identification of medical bacteria. Cambridge University Press, England

El Abd, Haleem D, Al-Thani RF, Al-Shammri M (2009) Isolation and characterization of polyaromatic hydrocarbons-degrading bacteria from different Qatari soils. Afr J Microbiol Res 3:761-766

Fetzer JC (2000) The chemistry and analysis of the large polycyclic aromatic hydrocarbons. Wiley, New York

Gemma E, Tomas C, Maria T, Gumersindo F, Juan M (2006) Enzymatic degradation of anthracene, dibenzothiophene and pyrene by manganese peroxidase in media containing acetone. Chemosphere 64:408-414

Harrigan EF, McCance ME (1976) Laboratory methods in food and diary microbiology. Academic Press, London

Heitkamp M, Franklin W, Cerniglia C (1988) Microbial metabolism of polycyclic aromatic compounds: isolation and characterization of a pyrene-degrading bacterium. Appl Environ Microbiol $54: 2549-2555$

Holt JG, Krieg NR, Sneath PHA, Stanley JT, William ST (1994) Bergey's manual of determinative bacteriology. Williams and Wilkins, Baltimore

Ilori MON, Amund DL (2000) Degradation of anthracene by bacteria isolated from oil polluted tropical soils. Z Naturforsch 55:890-897

Jonsen R, Lucas Y, Harms H (2005) Principles of microbial PAH degradation in soil. Environ Pollut 133:71-84

Kastner M, Breuer-Jammlia M, Mahroe B (1994) Emumeration and characterization of the soil microflora from hydrocarbon contaminated soil sites able to mineralize polycyclic aromatic hydrocarbons. Appl Microbiol Biotechnol 41:267-273

Levinson W, Stormo K, Tao H, Crawford R (1994) Hazardous waste clean-up and treatment with encapsulated or entrapped microorganisms. In: Chaudry GR (ed) Biological degradation and bioremediation of toxic chemicals. Chapman and Hall, London, pp 455-469

Lewis D, Hodson R, Freeman L (1984) Effects of microbial community interactions on transformation rates of xenobiotic chemicals. Appl Environ Microbiol 48:561-565

Mitchell J, Cain R (1996) Rapid onset of the accelerated degradation of dicarboximide. Pestic Sci 48:1-11

Nwachukwu BCU, James P, Gumey TR (2000) Inorganic nutrient utilization by "adapted" Pseudomonas putida strain used in the bioremediation of agricultural soil polluted with crude petroleum. J Environ Biol 22(3):153-162

Okerentugba PO, Ezeronye OU (2003) Petroleum degrading potential in single and mixed microbial cultures isolated from rivers and refinery effluent in Nigeria. Afr J Biotechnol 2(9):288-292 
Okpokwasili GC, Somerville CC, Sullivan M, Grimes DJ, Colwell (1986) Plasmid-mediated degradation of hydrocarbons by estuarine bacteria. Oil Chem Pollut 3:117-129

Pothuluri J, Cerniglia C (1994) Microbial metabolism of polycyclic aromatic hydrocarbons. In: Chaudry GR (ed) Biological degradation and bioremediation toxic chemicals. Chapman and Hall, London, pp 92-124

Shuttleworth KL, Cerniglia CE (1995) Environmental aspects of PAH biodegradation. Appl Biochem Biotechnol 54:291-302

Sikkema J, de Bont JA, Poolman B (1995) Mechanisms of membrane toxicity of hydrocarbons. Microbiol Rev 59(2):201-222

Smith JR, Nakles DV, Sherman DF, Neuhauser EF, Loehr RC (1989) Environmental fate mechanisms influencing biological degradation of coal-tar derived polynuclear aromatic hydrocarbons in soil systems. In: The third international conference on new frontiers for hazardous waste management. U.S. Environmental Protection Agency, Washington, DC, pp 397-405

Spain J, Pritchard P, Bourquin A (1980) Effects of adaptation on biodegradation rates in sediment/water cores for estuarine and freshwater environments. Appl Environ Microbiol 40:726-734
Van-Hamme J, Singh A, Ward O (2003) Recent advances in petroleum microbiology. Microbiol Mol Biol Rev 67:503-549

Walter U, Beyer M, Klein J, Rehm HJ (1991) Degradation of pyrene by Rhodococcus sp. UW1. Appl Microbiol Biotechnol 34:671-676

Wan N, Gu J, Yan Y (2006) Degradation of p-nitrophenol by Achromobacter xylosoxidans NS isolated from wetland sediment. Int Biodeterior Biodegred 59:90-96

West PA, Okpokwasili GC, Brayton PR, Grimes DJ, Colwell RR (1984) Numerical taxonomy of phenanthrene degrading bacteria isolated from the Chesapeake Bay. Appl Environ Microbiol 48: 988-993

Wilson SC, Jones KC (1993) Bioremediation of soil contaminated with polynuclear aromatic hydrocarbon (PAHs): a review. Environ Pollut 81:229-249

Yabuuchi E, Yano I, Goto S, Tanimura E, Ito T, Ohyama A (1974) Description of Achromobacter Xylosoxidans. Yabuuchi and Ohyama 1971. Int J Syst Bacteriol 24:470-477 